\title{
Some Historical and Contemporary Asian Elements in the Music and Performance Culture of Torres Strait
}

\author{
Karl Neuenfeldt
}

The Torres Strait region of northern Queensland has been significantly influenced by cultures originating in Asia. Along with other cultural artefacts and social practices, migrants from Japan, the Philippines, present-day Indonesia, Sri Lanka and elsewhere brought their musicianship, music and performance cultures with them. The rich musical culture of the Torres Strait region today is the result of these diverse Asian influences combining with the equally diverse heritage of the region's Aboriginal, European, Melanesian and Polynesian peoples.

This chapter examines some of the Asian elements in particular performance events. It also examines songs in the historical and contemporary Torres Strait musical repertoire. The examples are from the Torres Straits Pilot and New Guinea Gazette (hereafter Torres Straits Pilot), published on Thursday Island. The songs are remembered and sung primarily by the current oldest generation with Asian connections who lived in Torres Strait before World War 
II. After World War II, large-scale emigration from Torres Strait, ${ }^{1}$ the eventual demise of maritime industries and the decrease in Asian immigrants ${ }^{2}$ contributed to a decline in musical and cultural influences from Asia and Asians. Recent recordings, however, by Torres Strait Islanders are reintroducing Asian-influenced songs into the contemporary musical repertoire. ${ }^{3}$

The archival record of Asian musical influences in Torres Strait is limited, as are contemporary examples of the Asian-influenced musical repertoire. The historical record shows a very diverse migrant maritime workforce in Torres Strait. For example, 16 nationalities, 11 from Asia, were represented among the partial early death toll from the 1899 cyclone, which sank 66 luggers and seven tenders of the pearling fleet at Princess Charlotte Bay on the east coast of Queensland. ${ }^{4}$

\section{Historical Context}

Reportage of Asian involvement in Torres Strait performance culture needs to be appreciated in the context of the racial attitudes of the colonial and Federation eras. Anti-Asian sentiments were an integral part of the White Australia Policy, but were played out in Torres Strait in complex ways because of the importance of Asian labour for the maritime industries. ${ }^{5}$ Public culture was one forum in which the Anglo-European elite tolerated a degree of inclusiveness, in particular within musical, theatrical and civic events.

The historical record demonstrates clearly that Anglo-Europeans on Thursday Island held ambivalent racial attitudes towards the Asian and other non-White migrants who lived and worked among them. On one level, they were a key component of the society and commerce of Torres Strait; yet, at another level, they were a threat to the tenets of the White Australia Policy. The following examples show how musical performances, especially in connection with civic events such as Queen Victoria's Diamond Jubilee, became opportunities for the immigrants to present accessible, although often exoticised and patronisingly reported aspects of Asian performance culture.

\section{Examples of Historic Asian Elements in Performance Culture and Musical Repertoire}

An account of Christmas Eve celebrations on Thursday Island in 1897 provides a glimpse of colonial era performance culture there and its Asian elements. Thomas Eykyn, a visiting Church of England minister, relates how 'Manilamen labourers came to give their Christmas performance' with a band made up of 'a 
concertina, a penny whistle, and a lovely Japanese drum played with vigour, and without cessation'. 6 The songs performed included La Marseillaise, The Spanish Anthem, Grandfather Clock and Rule Britannia, examples of the eclectic and transnational repertoire already circulating on Thursday Island. A year later, in 1889, the anthropologist, Alfred Cort Haddon, documented the circulation of Asian music and cultural practices to other islands of Torres Strait. On Mer (Murray) Island during a local performance he attended, girls 'sang Japanese and other songs'. Moreover, some of the girls' faces were painted white with a bit of red pigment on each cheek. Haddon suggested this was 'perhaps in imitation of the Japanese women of the settlement in Thursday Island, which goes by the name of "Yokohama".?

Asian decorations at Anglo-European social events are sometimes the only historically documented indication of a sizeable Asian presence of domestic workers. At an evening's entertainment at his home in November 1903, Bishop White met parishioners while '[t]he grounds looked quite fairy like with festoons of Chinese and Japanese lanterns; and the attendance of the band enlivened, most appreciatively, the course of an enjoyable evening. ${ }^{8}$ Along with different decorations, musical performances were a way of making such occasions special.

It is important to note that, because Thursday Island was adjacent to an important international waterway and was also a coaling station, numerous professional entertainment troupes visited either while on tour in Australia and New Zealand or in transit to Asia and Europe, often performing at the local School of Arts. ${ }^{9}$ One example was the Beresford Variety Company, which visited Thursday Island in April 1901 after touring India. Beresford specialised in 'skate and pedestal and Hungarian top-boot dancing' and comedy, while Miss Mande Stamer was 'an accomplished singer soprano and pianiste'. ${ }^{10}$ Two years later, it was reported that the Carl Zell Society Entertainers offered 'brilliant entertainment of music, mirth, and mystery', presenting to local audiences 'Magic that has bewildered thousands! Music, vocal and instrumental, that has pleased thousands!'11

Alongside such professional troupes, community-based entertainment was an integral part of the local performance culture, which, out of necessity, had to draw on amateur performers. Asian communities participated directly in local performances and at key public events. Thursday Island's sizeable Japanese community participated in the Diamond Jubilee celebrations for Queen Victoria in June 1897. 


\title{
IN HONOUR of the CELEBRATION of the DIAMOND JUBILEE of HER MAJESTY the QUEEN of GREAT BRITAIN
}

\author{
The Japanese of Thursday Island will give a \\ DRAMATIC AND HUMOROUS \\ ENTERTAINMENT, \\ IN THE SCHOOL OF ARTS, \\ ON MONDAY EVENING NEXT, \\ At 8 o'clock. \\ Door opens at half-past seven. \\ Admission free. \\ The Committee reserve \\ the right of exclusion to anyone. \\ THE JAPANESE SPORTS COMMITTEE ${ }^{12}$
}

A review of the event appeared in the next issue of the Torres Straits Pilot. It reported that the event was well attended and 'strictly carried out after the Japanese fashion of portraying tragedy and comedy', with the 11 acts featuring a large cast 'of more or less grace and beauty'. ${ }^{13}$ At its conclusion, the Japanese present cheered in honour of Queen Victoria. The prominent businessman, Torajiro Sato, commented on the significance of the event. ${ }^{14}$ On behalf of the Japanese community, he expressed love and respect for the Queen and also said how glad they were that 'their lot is cast among such loyal subjects of Her Majesty's in this colony of Thursday Island'. ${ }^{15}$

In 1902, the Japanese community mounted another performance linked to British royalty. Although it was labelled an 'opera', it may have been a version of the kind of entertainment found in the rural area of Wakayama Prefecture where many of the Japanese migrants originated. ${ }^{16}$ The audience was told the 'opera' was composed especially for the coronation of the new British king. The Torres Straits Pilot's reviewer admitted no understanding of its aesthetic merits beyond surmising they 'were undoubtedly high ... if the appreciation of the large Japanese audience is to be a standard of judgement' and, overall, 'the whole performance in every detail was illustrated [sic] of the finer and higher side of Japanese life'. ${ }^{17}$ Of particular interest in the context of local politics was the donation of the performance's proceeds to the local Anglican Quetta Parish Institute. It suggests a conscious effort to ameliorate the perception that the Japanese community did not readily integrate, even though they were at that time by far the largest Asian population in Torres Strait as maritime workers and merchants. 


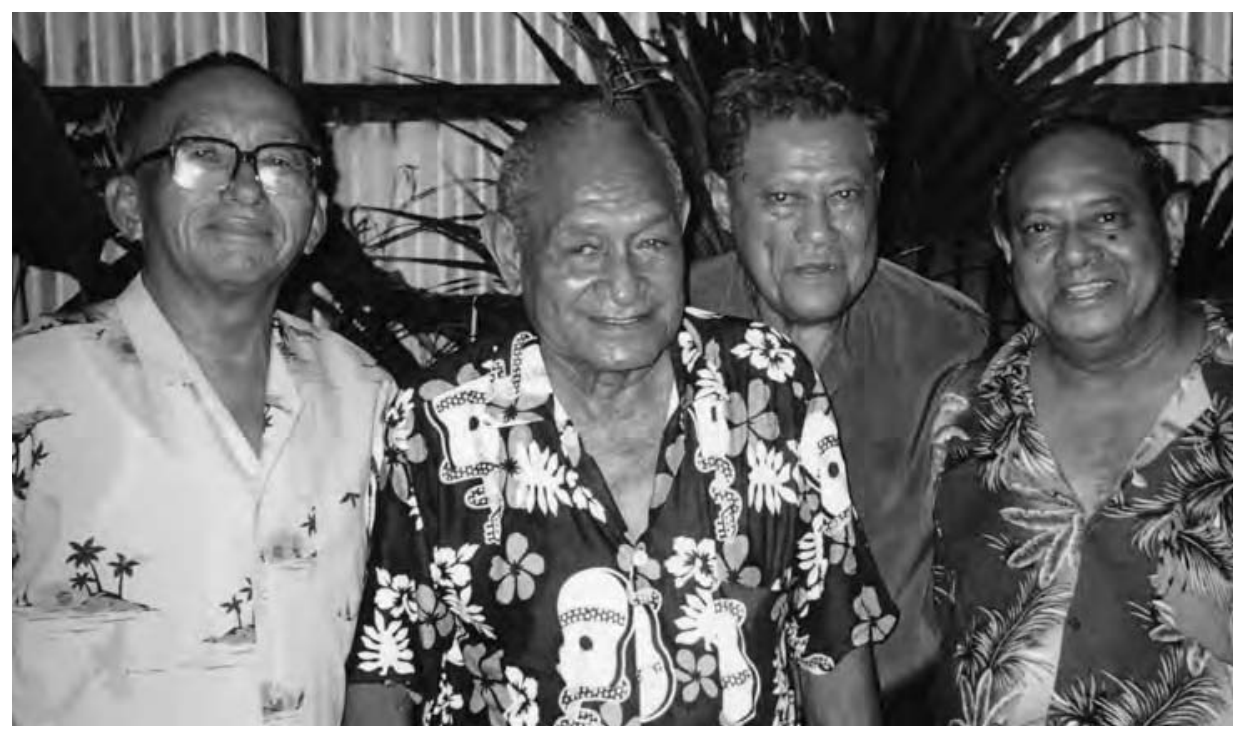

Thursday Island musicians. From left: Hismile (Izzie) Shibasaki, Henry (Seaman) Dan, Eveness (Jerry) Lewin and George Dewis (now deceased), c.1990-91. Courtesy of Karl Neuenfeldt.

Migrants from Sri Lanka, described variously as Singhalese or Cingalese, also presented public performances. One was the tale of Prince Ramlan and Princess Pew-lina. The Torres Straits Pilot's reviewer observed: 'It is not often that Thursday Island, not withstanding its large share of people of Eastern nationalities, sees a play, or a musical drama, for their amusement. ${ }^{18}$ The play was first read out in English and the reviewer commented on how well the actors acquitted themselves, with accomplished dancing, attractive dresses and makeup that was 'very handsome, as becomes the nature of all oriental people'. The account of another Sri Lankan performance also mentioned the contribution of $£ 1.15$ to the local hospital, analogous to Japanese donations to the Anglican Church's Quetta Parish Institute. The 'operas' were described as 'curiously oriental in their character' and were 'undoubtedly appreciated by the coloured element', although 'their efforts to please were responded to only in the main by coloured people'. ${ }^{19}$

In 1903, a 'goodwill visit' by Japanese naval vessels was accompanied by several musical events, which included repertoire based on the British brassband tradition: 'the band was brought up from the ship and provided music of a high class character. There was evident enjoyment and a full appreciation of a Japanese war ship's band playing at the Grand Hotel on Friday afternoon.'20 
The importance of music to the pageantry and the success of the visit was remarked widely. The Torres Straits Pilot recorded how 'the interest in the visit was considerably enhanced by the band, the like of which was never before heard here, and it may be a long time ere such music may be heard again'.21 Months later, favourable remarks were still being made about the quality of the Japanese naval band, which had set a standard of comparison for local bands. Commenting on a local band, it was said: 'The ... band has made wonderful progress ... and they now perform in a style which places them in a high class ... said some one on Thursday evening last at the concert, "they remind you of the Japanese band" which was not bad.'22

By the 1930s, Asian migrants and their descendants had become very active in community performances on Thursday Island, in some ways challenging the previous Anglo-European dominance. One example of this was a 'Grand Concert' put on by the Merry Magpies at the Town Hall on Monday, 3 September, 1934. Included in the program were dance items such as a 'Malay dance', 'ribbon dance' and a 'paddle dance', performed by community-based entertainers with Asian family names: Ahfat, Bargo, Bin Garape, Sariman and Subideen. The program also included plantation songs out of the North American minstrelsy tradition, such as Kentucky Home performed by 'Sambo and Alabama'. One can only speculate as to whether the singers and dancers of Asian heritage 'blackened up' to perform the plantation songs.

Overall, archival newspaper evidence substantiates the claim that Asians, whether presenting their own or imitating other music, contributed to the historic performance culture of Torres Strait and complemented the performance traditions of the dominant (but minority) Anglo-European community. Although direct Asian influence waned with regional and national political, social and economic changes after World War II, traces of Asian musicality and repertoire endure in Torres Strait today, in old and new songs.

\section{Examples of Contemporary Asian Elements in Performance Culture and Musical Repertoire}

The following songs are examples of mainly South-East Asian influences in the contemporary music repertoire of Torres Strait Islander communities and performers in Torres Strait and on the mainland. Some biographical information about the Asian heritage of various singers and writers is also given as context. What are often referred to locally as 'Malay' songs can be typified as romantic or nostalgic songs with memorable melodies. ${ }^{23}$ Musically and lyrically, they evoke a certain cultural and geographic ambience associated with presentday Indonesia and the Philippines. Linguistically, they often combine 'Malay' 
and English words, as few contemporary performers are fluent in modern-day Bahasa Indonesia or the Filipino Tagalog language. Depending on the origin of their parents and grandparents, elderly performers and composers may, however, have learned and spoken one of many regional Asian languages and dialects. Nonetheless, the use of 'Malay' words and phrases signifies an overt Asian connection.

Eveness (Jerry) Lewin (born 1927) traces his family's Asian heritage to present-day Indonesia. ${ }^{24}$ Along with other non-combatants living on Thursday Island at the outset of the Pacific War, his family was evacuated to the Australian mainland in January $1942 .{ }^{25}$ He remembers that before they left he often heard 'Malay' songs at house parties frequented by migrant maritime workers. He recalls, in particular, hearing the well-known Indonesian song, Bengawan Solo, written by Gesang Martohartono in 1940. He must therefore have heard it just before his family was evacuated. He recalls it being sung during the war years along with other 'Malay' songs that reminded evacuees of home. While on the mainland he worked in various manual jobs in southeastern Queensland, but also learned music, especially from Filipinos attached to the US military. When Jerry returned to Torres Strait in the late 1940s, like many other men of his generation, he worked in the maritime industries. One of the boats he worked on was called the Bada Kris, a 'kris' being a kind of knife. It was a barge converted for trochus-shell harvesting and carried a crew of 10 men. It would return to port when it had a full load of trochus shells or when it needed provisions. He wrote a song about it in 1950 when working the Great Barrier Reef out of Cairns, north Queensland. In 2002, Jerry recorded the song for a community CD called Sailing the Southeast Wind: Maritime Songs from Torres Strait:

Jangan lupa nona manis / classie Bada Kris / belung slamat tinggal / kita skarang mau blihar / tinggal nona nona samuah / susah hati te dalam ada sato / bulan kita con balek

Translation: Don't forget my sweetheart the barge Bada Kris / saying goodbye to you / we shall be going / be going to our sweethearts in Cairns / I love her with all my heart / she is the only one / I shall return on the first moon and I'll be back in Cairns.

George Dewis (1935-99) traced his family's Asian heritage to the Ambon region in Indonesia and to Timor. He was one of the few Thursday Islanders of Asian descent to visit Indonesia, which he recalled was an interesting experience because some of the music was familiar as were other cultural practices. ${ }^{26} \mathrm{He}$ was also recognised for his Asian-influenced cooking skills, which were put to good use first while working as a cook on pearling and 
trochus boats and later at community events. He was a skilled musician and singer and recorded a version of the well-known Indonesian song, Nona Manis, for a community CD called Strike Em!: Contemporary Voices from Torres Strait. ${ }^{27}$ It combines 'Malay' and English words:

Goodbye to you my Nona Nona Manis / Don't you forget junang lupa kapada siam / but in your eyes you will always think of me saya da limpe kapada siam.

An indication of the continuing significance of such Asian-influenced songs is that his recorded version of Nona Manis was played at his tombstone unveiling ceremony in 2002, the key Torres Strait Islander social event that marks the end of the mourning period. ${ }^{28}$

Ernest Ahwang (born 1941) traces his family's Asian heritage to the Singapore Strait settlement. He was just a baby in 1942 when his family was evacuated on the small pearling lugger, Goodwill, the same boat Jerry Lewin's family was on. He was raised in Mackay, Queensland, where he learned 'Malay' songs at community events and from his uncle, Norunnie (Rocky) Ahwang. Ernest recorded an instrumental version of Terang Bulang for the National Museum of Australia's Torres Strait Islander exhibition Paipa/Windward. He also recorded another song he titled Bala Ernest. It is based on South-East Asian guitar styles known loosely in the community as 'kronchong' songs, although they are not overly similar to the well-known Indonesian style. Because the 'Malay' songs have memorable melodies, they lend themselves either to instrumental versions or to new songs, in the sense that they combine some of the 'Malay' words with new English ones.

Hismile (Izzie) Shibasaki (born 1929) traces his family's Asian heritage to Japan and Malaka. ${ }^{29}$ His family was also evacuated in early 1942 and spent the war years mostly in the Bundaberg area of Queensland. As a Japanese citizen, Izzie's father, Kyukichi, was interned as a prisoner of war, but was allowed to return to Thursday Island after the war because his wife was born in Torres Strait and he was a skilled pearl diver. Izzie recalls that before evacuation and during the war years 'Malay' music in particular was an important part of social life. His mother sang 'Malay' songs to him as a child and they were sung at house parties. A particular favourite was Nona Manis Siapa Yang Punya, ${ }^{30}$ which Izzie still sings when performing. The version below is from a Japanese-based web site. ${ }^{31}$ It is interesting that the lyrics are in Bahasa Indonesia and English, similar to the transliteration routinely heard in Torres Strait songs: 
Nona Manis siapa punya / Nona Manis siapa punya / Nona Manis siapa punya / Rasa sayang sayange / Baju merah siapa yang punya / Baju merah siapa yang punya / Baju merah siapa yang punya / Rasa sayang sayange / Ingat ingat it remember / Jangan lupa itu don't forget / Aku cinta itu I love you / Hanya kamu only you.

Translation: Pretty girl whose fiancee is she / She is very charming / Wearing white dress whose fiancee is she / She is very charming

Wayne See Kee (born 1971), who traces his family's Asian heritage to China, completed a university degree in Asian studies. He has been involved in Torres Strait Islander music as a radio broadcaster, performer and writer and wrote a contemporary romantic song called Saya Patu Kamu, which translates from 'Malay' to English as 'I love you'. He recalls: 'I wrote it as a love song, and I was looking for a Torres Strait language to use, but couldn't find an appropriate phrase. I noticed a lot of the Malay descendants on Thursday Island still used this phrase with little children so I decided that it sounded good in the song.' ${ }^{32}$

When will you say you love me saya patu kamu / When will you say you care for me saya patu kamu / When will you say you want me saya patu kamu / When will you say I'm the only one saya patu kamu / Though the world could stand still I'll be waiting here for you / Just to hear three special words that will tell me you're so true / When will you say you love me saya patu kamu.

There is at least one song in the older Torres Strait repertoire associated with Japan, a song called Japanese Rumba. Edwards typifies it as a Japanese folk song and, according to an Islander informant, 'the dance that was associated with it also owed something to the oriental style of dancing, with the actions being very formal'. 33 The lyrics are:

Japanese rumba ia ia $i$ / Japanese rumba ia ia $i$ / Japanese rumba ia ia i / suda nassi, suda resun / combowa, combowa / whya suda remus HA. ${ }^{34}$

Another song with a possible connection to Japan is a boat song called Hossack H, which was recorded for the National Museum of Australia's Torres Strait Islander exhibition, Paipa/Windward, in 2002. Informants in Mackay, where it was recorded, suggested it might be a transliteration of 'Osaka'. Given the dominance of Japanese in the maritime industries, it is understandable that aspects of their music would be learned or assimilated by Islanders. Hayward and Konishi include songs that were written by Japanese maritime workers about their life in Torres Strait. ${ }^{35}$ The traffic in songs went both ways: elderly Japanese ex-divers remembered Islander songs when interviewed in 1999. 


\section{Conclusion}

Some songs in the current Torres Strait Islander repertoire show clear Asian influences, mostly in versions of songs popular when migration from Asia was common. Most of the older songs in the repertoire have been indigenised in the sense that there has been language substitution and in some cases localisation of themes. Large-scale migration all but ceased with the outbreak of World War II and consequently few, if any, new Asian songs have been introduced since then. Current recordings of some of the songs are reintroducing them to new audiences and performers and they may well remain as a reminder of the cultural impact of Asia on Torres Strait and Torres Strait Islander performance culture.

\section{Footnotes}

1 Beckett, J. R. 1987. Torres Strait Islanders: custom and colonialism. Cambridge University Press.

2 Ganter, R. 1994. The Pearl Shellers of Torres Strait: resource use, development and decline 1860s-1960s. Melbourne University Press.

3 It needs to be noted that Torres Strait is not the only region of northern Australia where Asianinfluenced music and dance are still performed. For example, during the Darwin Festival of Arts in the Northern Territory in August 2002, two performances were linked overtly to Asia. A Filipino shake-hand dance was performed and the Rondella String Band played music in the style of Filipino string bands. In Western Australia, Broome has long celebrated its Asian linkages in the music of artists such as the Pigram Brothers, who write about the mixed heritage of the community using 'Malay' words and phrases that have become part of the local language. Historical examples of these linkages are noted in Bain, M. 1982. Full Fathom Five. Perth: Artlook Books.

4 Torres Straits Pilot 13 May, 1899. p. 1.

5 Mullins, S. 1995. Torres Strait: a history of colonial occupation and culture contact 1864-1897.

Rockhampton: Central Queensland University Press. Ganter, R., The Pearl Shellers of Torres Strait.

6 Eykyn, T. 1896. Parts of the Pacific. London: Swan Sonnenschein. p. 99.

7 Haddon, A. C. 1901. Head-Hunters: Black, White, and Brown. London: Methuen. pp. 36-7.

8 Torres Straits Pilot, 7 November, 1903. p. 1.

9 See, for example, Bandmann, D. 1886. An Actor's Tour or Seventy Thousand Miles with Shakespeare. New York: Bretano Brothers. Mullins, S. and K. Neuenfeldt. 2001. 'The "saving grace of social culture": early popular music and performance culture on Thursday Island, Torres Strait, Queensland.' Queensland Review, Vol. 8, No. 2. pp. 1-20.

10 Torres Straits Pilot, 18 April, 1901. p. 1.

11 Torres Straits Pilot, 21 November, 1903. p. 1.

12 Torres Straits Pilot, 19 June, 1897. p. 1.

13 Torres Straits Pilot, 26 June, 1897. p. 1.

14 Hayward, P. and J. Konishi. 2001. 'Mokuyo-to no ongaku: music and the Japanese community in the Torres Strait (1890-1941).' Perfect Beat, Vol. 5, No. 3. p. 48.

15 Torres Straits Pilot, 26 June, 1897. p. 1.

16 Hayward, P. and J. Konishi, 'Mokuyo-to no ongaku'.

17 Torres Straits Pilot, 5 July, 1902. p. 1.

18 Torres Straits Pilot, 18 May, 1901.p. 1.

19 Torres Straits Pilot, 1 February, 1902. p. 1. 
20 Torres Straits Pilot, 4 July, 1903. p. 1.

21 Torres Straits Pilot, 11 July, 1903. p. 1.

22 Torres Straits Pilot, 31 October, 1903. p. 1.

23 See Neuenfeldt, K. 2002. 'Examples of Torres Strait songs of longing and belonging.' Journal of Australian Studies, No. 75. pp. 111-16.

24 Jerry Lewin, pers. comm., 2002.

25 Osborne, E. 1997. Torres Strait Islander Women and the Pacific War. Canberra: Aboriginal Studies Press.

26 George Dewis, pers. comm., 1999.

27 Neuenfeldt, K. 2001. 'Cultural politics and a music recording project: producing Strike Em!: Contemporary Voices from the Torres Strait.' Journal of Intercultural Studies, Vol. 22, No. 2. pp. 133-45.

28 Fuary, M. 1993. 'Torres Strait cultural history.' In N. Loos and T. Osanai (eds), Indigenous Minorities and Education, Tokyo: Sanyusha. pp. 165-86.

29 Hismile Shibasaki, pers. comm., 2003.

30 Edwards, R. 2001. Some Songs from the Torres Strait. Kuranda: Ramskull Press. pp. 148-9. Edwards claims that Nona Manis Siapa Yang Punya was adopted and adapted by Australian troops during World War II. Kartomi (cited in ibid., p. 149) says the song originated in Maluku in Ambon and became ubiquitous in Indonesia after 1949.

31 http://www.alles.or.jp/ longisl/ songe.html

32 Wayne See Kee, pers. comm., 2003.

33 Edwards, R., Some Songs from the Torres Strait, p. 75.

34 There were Okinawan divers in Torres Strait after World War II and P. Hayward and J. Konishi, 'Mokuyo-to no ongaku', p. 64, note there is some dispute over the exact origins of the song, citing the work of Hosakawa, S. 1999. 'Soy sauce music: Haruomi Hosono and Japanese self-orientalism.' In P. Hayward (ed.), Widening the Horizon: exoticism in post-war popular music, John Libbey/Perfect Beat Publications. pp. 114-44.

35 Hayward, P. and J. Konishi, 'Mokuyo-to no ongaku', pp. 56-8. 


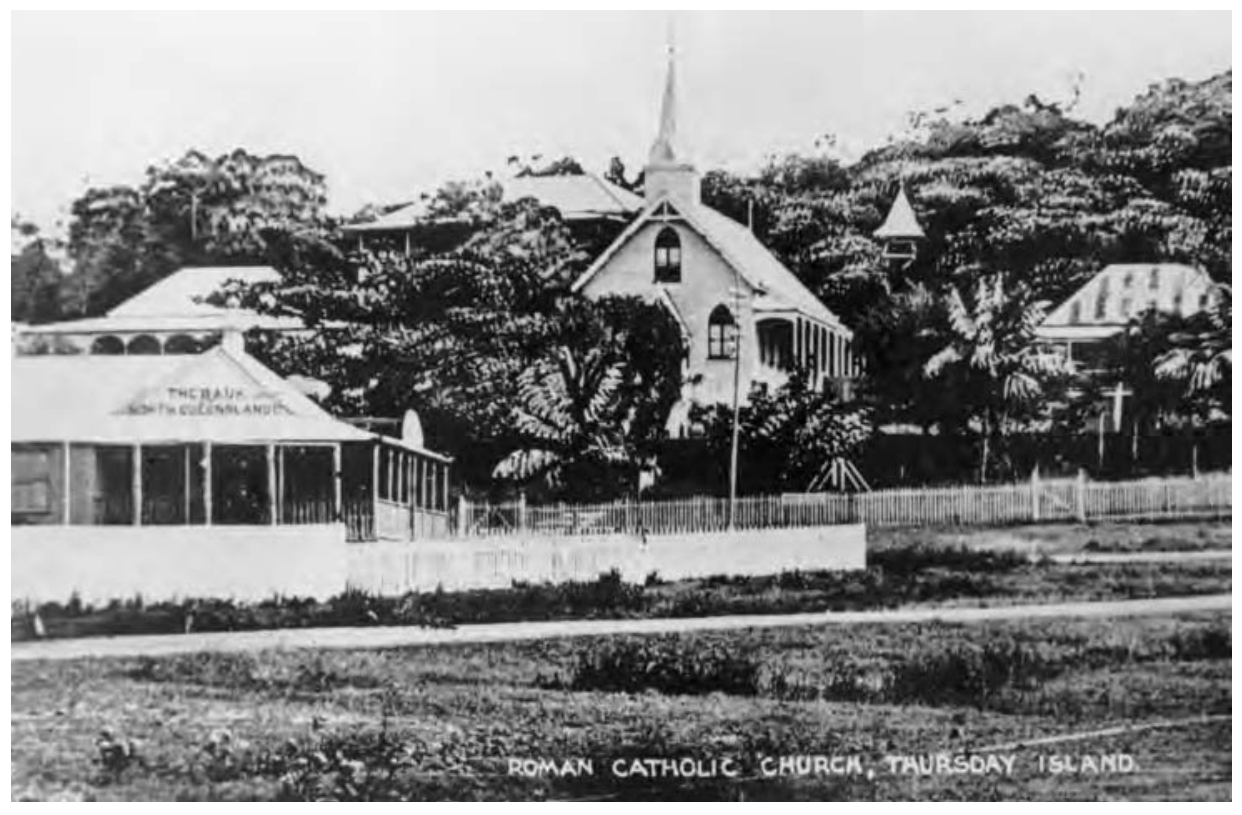

Roman Catholic Church, Thursday Island, 1906.

Courtesy of John Oxley Library, Brisbane (Item No. 1618). 
This text is taken from Navigating Boundaries: The Asian diaspora in Torres Strait, edited by Anna Shnukal, Guy Ramsay and Yuriko Nagata, published 2017 by ANU eView, The Australian National University, Canberra, Australia.

dx.doi.org/10.22459/NB.11.2017.11 